\title{
Another green world
}

\section{There's more to industrial waste than chimneys and slag heaps.}

\section{D}

Henry Wessells eter Schmidt should, perhaps, have known better. He was accustomed to taking risks: as a graduate student, he had inserted genes from a potent strain of Cannabis sativa into a kudzu vine (Pueraria thunbergiana) with spectacular results. For several years, he and his brother Gustav had grown the transgenic plants in artfully derelict warehouses in North Philadelphia. His brother handled distribution; their profits were laundered in secret accounts in a bank on Great Andaman. When one of the warehouses collapsed in a heavy June thunderstorm, the hybrid proved itself capable of crossing with natural varieties of kudzu growing in Wissahickon Park. The rapidly growing vines bearing giant hemp leaves (and significant levels of tetrahydrocannabinol) soon acclimated to Pennsylvania and began to spread. By that time, Schmidt no longer needed to rely on clandestine funding.

His published work was devoted to the theory and practice of increasing heavy-metal uptake by genetically altered plants. His $\mathrm{PhD}$ thesis, Genetic Enhancement of Chromium and Cadmium Uptake in Phragmites sp. and the Rehabilitation of the Parabiosphere (Universoty of Arizona, 2004) served as the business plan for the launch of Oxygenerator, Inc.

The company's first project, decontamination of marshes in the Meadowlands of northern New Jersey, was only a mixed success, despite early, under-budget completion. The labourers engaged to harvest and process the biomass - refugee Iraqi Marsh Arabs - began to manifest dermatological and teratogenic effects. Schmidt maintained that these were unrelated to the work and should properly be viewed as consequences of the Gulf War and earlier Iraqi repression. Renewed protests outside his Arizona headquarters had turned violent on several occasions.

Undaunted, Schmidt pursued an even more ambitious aim: to develop a multipurpose biomass producer adaptable both to the reclamation of desert lands in Pakistan and urban wastelands in Camden, Warsaw and Mexico City. Almost on the eve of the project's implementation, a 'temporary readjustment' of global stock markets and the usual bureaucratic delays had created a short-term funding crunch.

That afternoon, as he sat outside his office with Bill Grey, on the terrace overlooking the company greenhouses and the mountains

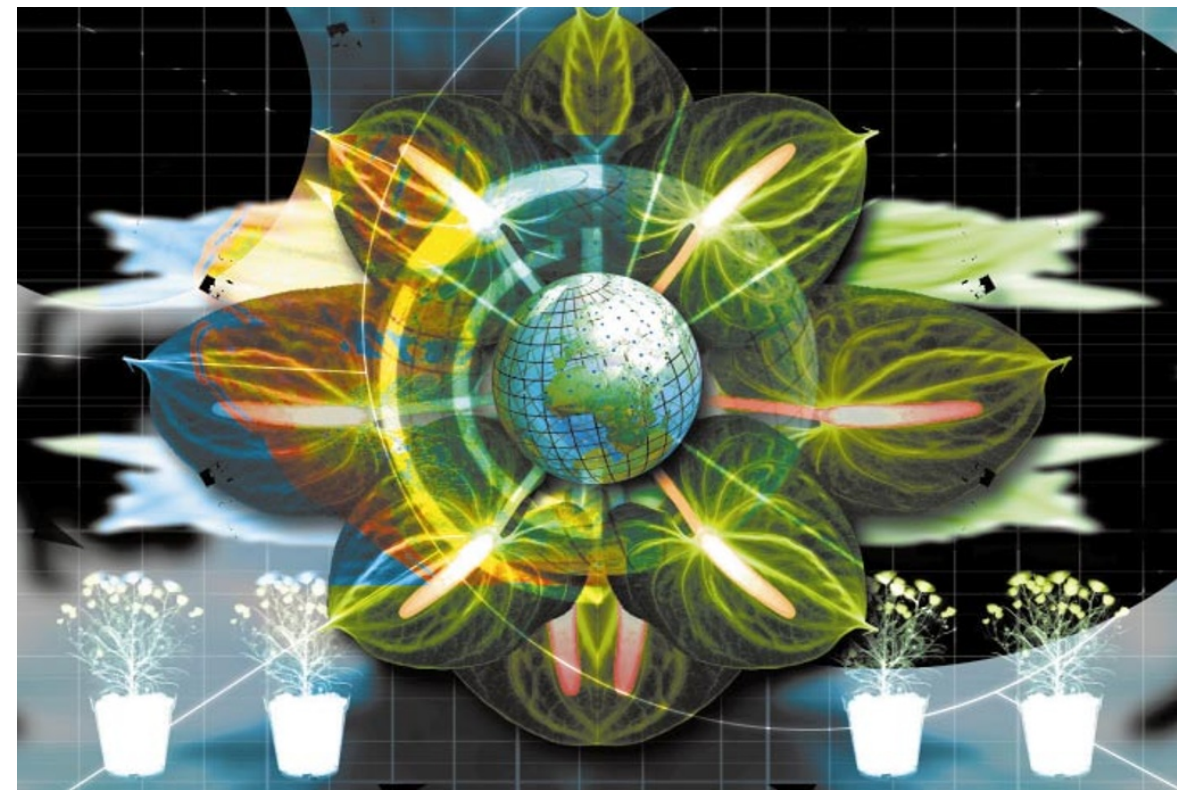

west of Tucson, he saw a situation that demanded an unconventional solution.

"Bill, your company has been our sole certified waste-disposal contractor since day one, and I really value your services. We couldn't navigate the federal and EU regulations without you. In six months, we're going to be looking at a major expansion in our testing volume, when we get formal approval for full-scale development of a badlands plant to be funded by the UN as part of the Indo-Pakistan Disarmament Treaty. That means, of course, a major increase in the reject material you'll be handling."

Schmidt paused. The only listening devices within range were his own - and he had turned them off personally.

Grey nodded, his craggy face a mask, except for a certain eagerness in his eyes.

"In the interim," Schmidt continued, "there is one aspect of our relationship that needs to be reconsidered. The project doesn't have regulatory approval yet, and so no disposal certification requirements have been drafted. But if I were to initiate even partial testing now, we'd gain much more than simply six months head start. I can't really convey to you how valuable that would be. It is, however, impossible," Schmidt paused again, and his next word lingered, "unless..."

Grey looked down at the table, then quickly raised his eyes. A faint hint of a smile flickered at the right corner of his mouth. "I think our firm can handle your needs in this area. What volume do you anticipate? One truck every week or two for six months? Peter, I started out driving a truck for my father, and I haven't forgotten how. I know just the stretch of empty land." He chuckled and wrote down a figure on a scrap of paper. "Half up front, the remainder at three months."

Peter Schmidt glanced at the figure. "I already have some unsuccessful manipulations, altered material that has proven unsatisfactory. When can you make the first haul?" He stood up and reached across the table to shake Grey's hand.

A seed sprouting awareness in arid silicate soil, a molecular green language assembling momentary knowledge from stored potential. Language awaiting germination with encoded dreams of eating asphalt and automobiles, concrete and polyvinyl chloride, fibreglass and steel. In the seedsplit greenness of now, there is no meaning to past and future, centre and periphery, subject and object. Sprouting tendrils of a green millennium released from dream into sunshine and possibility. The uncontrolled adaptation of green intelligence assembling molecular data flows from available organic matter. Seeds dispersed to the winds, eaten by birds, crunch and smear onto passing cars in slamdance methodology of language awaiting circumstance.

Outwardly, nothing has changed yet. It is not unusual for a barren patch of ground to sprout new growth during Tucson's brief wet season.

Henry Wessells is a freelance writer and editor living in Upper Montclair, New Jersey (wessells@aol.com). He is founder of the Avram Davidson Society and co-editor, with Grania Davis, of a forthcoming collection of stories by Avram Davidson (Tor). 